\section{Museum pieces}

SIR - Halstead's progress report on the death of scholarship and the rise of Marxism in the Natural History Museum (Nature 20 November ${ }^{1}$ ) mixes too many different issues for a full reply. I will concentrate on his attack on scholarship in this institution. To Halstead, the symptom of decay is advocacy, in the public galleries, of cladistics, a method which he believes is being forced down the public throat by a Public Services Department which has overridden the views of scientists in the Museum.

Cladistics, as presented in the "Dinosaur" and "Fossil man" exhibits, may indeed seem oversimplified to some, or not fully thought through to others. But Halstead's alternative approach, as detailed in his comments on fossil man, seem to me far more grievously mistaken. In accusing us of lack of scholarship, he offers instead "the well attested sequence of human fossils representing samples of succeeding populations has . . . been taken as a classic example of the gradual evolution of a single gene pool. Certainly there is not any serious doubt about Homo erectus being directly ancestral to Homo sapiens". Confronted with these statements, one must either bow to Halstead's scholarship, or ask "attested"' by whom? "been taken" by whom? "not any serious doubt" by whom? Halstead's answer might be, to quote the Museum handbook to the old exhibit on fossil man which was removed to make way for the dinosaurs, "the evolution of Man has come to be regarded as fact rather than hypothesis by all persons qualified to judge the evidence", 2 . In other words, we (scientists, experts, authorities) tell you it is so.

The radical departure in the exhibit reviled by Halstead is that the voice of authority is less strident. The visitor is encouraged to understand, and to take part in, the reasoning that underpins the story of human evolution; to become one of those "persons qualified to judge the evidence". And cladistics is the logical entry to that reasoning.

Amongst scientists in the Museum there are many different viewpoints on the value and generality of cladistic methods. Those viewpoints are a symptom of activity and debate. Halstead opts out of the debate, deferring instead to the authority of Mayr and Simpson, of books published 30 or 40 years ago, "and indeed of Charles Darwin himself". From his "reading of the literature of cladistics" Halstead concludes that cladists form the opposition " $t 0$ the concept of gradualism and to the idea that the processes that can be observed at the present day, when extrapolated into the past, are sufficient to explain changes observed in the fossil record" This last idea, of extrapolating the present into the past as sufficient explanation, is usually attributed to Charles I yell under the name uniformitarianism. I yell's uniformitarian explanation of the changes observed in the fossil record was piecemeal extinction and creation ${ }^{3}$, an explanation invoking

"qualitative leaps". Indeed, T.H. Huxley himself was unable fully to accept Darwin's gradualism, and preferred the saltationist camp. In short, Halstead's equation of cladistics and saltation is simply mistaken.
Recent advocates of saltation, and critics of extrapolation from population genetics to macroevolution, such as Gould ${ }^{4}$ and Stanley ${ }^{5}$ are not cladists. Whether they are Marxists is another matter, in my view an irrelevant one.

More relevant is Halstead's confusion over the relation between cladistics, a method of systematics, and questions of process modes of speciation or transformation of species. He sees a necessary connection between cladistics and one view of the evolutionary process, but as cladistic literature makes plain ${ }^{6-8}$, there is no such connection. Cladistics is not about evolution, but about the pattern of character distribution in organisms, or the recognition and characterization of groups. Halstead might direct his search for Marxist propaganda towards the Nuffield Biology texts and guides, for the teacher is urged "to develop a common vocabulary (and possibly notation) in biology and mathematics" by teaching the elements of systematics through Venn diagrams, which are logically synonymous with cladograms ${ }^{8}$. All that seems to lie behind Halstead's complaint is his failure to grasp the distinction between pattern (systematics) and process (explanation of the pattern $)^{9}$. Hence his mistaken belief that he knows how evolution works, and that we are unwittingly committed to Marxist historicism.

Colin Patterson

Department of Palaeontology,

British Museum (Natural History), London SW7, UK

Halstead, L.B. Nature 288, 208 (1980).

de Beer, G.R. Evolution 4th edn (British Museum (Natural History) London, 1970).

3. Oldroyd, D.R. Darwinian Impacts (Open University Press, Milton Keynes, 1980)

4. Gould, S.J. Paleobiology 6, 119-130 (1980)

5. Sianley, S.M. Macroevolution (Freeman, San Francisco, 1979).

Platnick, N.1. Syst. Zool, 26, 438-442 (1977).

7. Platnick, N.I Syst. Zool 28, 537-546 (1980).

Eldredge, N. \& Cracraft, J. Phylogenetic Patterns and the Evolutionary Process (Columbia University Press, New York, 1980)

SIR--In Dr Halstead's pleas for traditionalism in the Natural History Museum's exhibitions (Nature 20 November, p.208) he makes an assumption that lends much potential support to those whose policies he is so "fervently dedicated" to trying to discredit.

It is true that Marxists have attempted to equate the idea of punctuated equilibria (in its many guises) with the principles of dialectic, the head-on collision between changed environment and less well adapted organisms giving rise, by dialectic confrontation, to the new 'adapted' order, exactly as Marx envisaged the clash of the bourgeoisie and the proletariat, though Marx himself was somewhat vague in this area. Gradualism has been called on as evidence for other political persuasions. Politicians of all colours of the political spectrum have found things in Darwinism to support their political positions. As Shaw says of Darwin, "He had the luck to please everybody who had an axe to grind".

Unfortunately Dr Halstead is himself supporting the tenuous link between change in historical and present day human societies; between so-called "cultural evolution" (which is a true Lamarckian system in any case) and the far slower and partially understood process of biological evolution, he is approving the idea that supposed historical events in evolution can be used as "scientific" evidence to predict and explain cultural evolution. Dr Halstead has only got under the surface of the argument, not to its core; he would surely be far better off questioning this primary assumption, rather than unintentionally lending support to biologically naive political thinkers. If he could do this, the problem he feels so strongly about would evaporate and he could escape. As it is, he is in great danger of being trapped by his position; his gradualist evidence is more tenuous than he implies, and since the recent Chicago conference it is probable that punctuated equilibria will indeed become a new orthodoxy. How will Dr Halstead free himself? With a "mighty leap" - a method some orthodox neo-Darwinians have been known to use?

The confirmation of his superficial attitude is given by his statement that, "Marxism will be able to call upon the scientific laws of history in its support". Dr Halstead clearly believes, as, of course, Marx did, that such "scientific laws of history" exist, but their emptiness has been elegantly demonstrated by Sir Karl Popper in The Poverty of Historicism, and The Open Society and its Enemies.

Having read Dr Halstead's views on

Popper elsewhere I am not surprised at all by his confusion.

M. J. HughES-GAMES

Clifton,

Bristol, UK

SIR - L.B. Halstead's letter (Nature 20 November, p.208) is misguided and, if his arguments were generally accepted, dangerous to the unfettered development of science. Whatever the scientific merits and demerits of the "cladist" theories behind the Natural History Museum's “Dinosaur" and "Fossil man" exhibits, it is most certainly wrong to attack them on the grounds that they might provide support for " $a$ fundamentally Marxist view of the history of life". Indeed, it is ironic that Halstead should quote J.V. Stalin, for it was precisely his policy of encouraging the application of political criteria, rather than scientific ones, to assess scientific theories that ruined so much Soviet science for a generation.

It is really quite silly of Halstead to argue that because Marxist philosophers believe in revolutionary leaps (and, incidentally, so do several other, and quite different, philosophical and sociological schools of thought) then we ought to reject any scientific theory that explains changes in specific phenomena by way of "an abrupt leap from one state to another". How far is Halstead prepared to go with this "critique"? Should cosmologists now be called upon to reject the "big bang theory", topologists "catastrophe theory" or historians of science "paradigm breaks" because they might be construed as support for a law of Marxist dialectics?

Technology Policy Unit,

HARRY ROTHMAN

Birmingham, UK 